\title{
Conversion of Palm Oil (CPO) into Fuel Biogasoline through Thermal Cracking Using a Catalyst Based Na-Bentonite and Limestone of Soil Limestone NTT
}

\author{
Daniel Silalahi ${ }^{1} \square$ Minto Supeno ${ }^{2}$ and Muhammad Taufik ${ }^{3}$ \\ ${ }^{1}$ Postgraduate School, Department of Chemistry, Faculty of Mathematics and Natural Sciences Universitas Sumatera Utara, \\ Medan, Indonesia \\ ${ }^{23}$ Department of Chemistry, Faculty of Mathematics and Natural Sciences Universitas Sumatera Utara, Medan, Indonesia
}

$\square$ Corresponding Author: Daniel Silalahi, E-mail: andreandreas764@gmail.com

ARTICLE INFORMATION ABSTRACT

Received: 08 October 2021

Accepted: 14 October 2021

Published: 10 November 2021

DOI: 10.32996/ijbpcs.2021.3.2.1

\section{KEYWORDS}

Bentonite, Biodiesel, CPO, Catalytic cracking, saponification
Cracking catalytic palm oil (CPO) into hydrocarbon fuel by saponification pretreatment has been carried out with bentonite and limestone-based catalysts. The catalysts used were Na-bentonite and Limestone NTT which were first analyzed using $X R F, X R D$, and SEM. Saponification pretreatment was carried out on CPO to facilitate the cracking process using a catalyst. The saponification product in the form of a mixture of soap and glycerol was then analyzed by DSC to determine the degradation temperature. Catalytic cracking is carried out in two stages, namely, the first stage hydrocracking at a temperature of $250-350^{\circ} \mathrm{C}$ using a stainless steel reactor is the source of catalyst Fe / Cr. The resulting distillate was then cracked again using a $\mathrm{Na}$ bentonite catalyst and a TKNTT catalyst. The resulting fuel is a hydrocarbon fuel which is confirmed from the FT-IR results which indicate the presence of long-chain hydrocarbon compounds. This data is also supported by the results of the GC-MS analysis which shows that the fuel fraction produced is mostly biogasoline. Where cracking using a Na-bentonite catalyst produces a biogasoline fraction of $61.36 \%$ and a biodiesel fraction of $38.63 \%$, THAT produces a biogasoline fraction of $88.88 \%$ and a biodiesel fraction of $11.11 \%$. The characteristics of the hydrocarbon fuels that have been analyzed show that the calorific value of combustion is $6101 \mathrm{cal} / \mathrm{g}$ which is determined using a bomb calorimeter, and the cetane index is 62 which is analyzed using $\mathrm{CCl}$. Both types of hydrocarbon fuels have met the physical requirements that must be possessed by biogasoline fuel based on SNI standards.

\section{Introduction}

Fossil fuels have been used as the main energy source for many years but their use is unsustainable and causes environmental problems associated with burning fossil fuels. Fossil fuels are natural resources that cannot be renewed so that their availability is increasingly limited, while the demand for energy needs for various industrial activities and meeting the needs of human life is increasing day by day (Radionova et al., 2016). In addition, the use of fossil fuels is not environmentally friendly and harmful to health because the burning of fossil fuels produces hazardous compounds such as $\mathrm{NOx}, \mathrm{SOx}, \mathrm{Pb}, \mathrm{CO}$, and other particulate compounds (Donatus 2015). Due to the high demand for fossil fuels, alternative fuels are needed that can replace fossil fuels. Biofuels have been studied to have great potential as a substitute for fossil fuels. Biofuels consist of biofuels gas and biofuels liquid and are usually produced from renewable natural resources. Biofuel Gas Consists of methane and hydrogen and biofuel liquid consists of biogasoline and biodiesel (Ahmad et al., 2016). In addition, biofuel is an environmentally friendly fuel because it does not contain nitrogen and sulfur compounds (Junifa, S. 2020).

Crude Palm Oil (CPO) is one of the potential alternative energy sources to replace fossil fuels, this is because palm oil has a long carbon chain similar to the hydrocarbon chains in fossils. Therefore, Crude Palm Oil can be processed to produce alternative fuels (biofuels) such as biodiesel and biogasoline which are possible to replace fossil fuels (Nurjanah et al., 2013). In 2011, Oil

Copyright: (c) 2021 the Author(s). This article is an open access article distributed under the terms and conditions of the Creative Commons Attribution (CC-BY) 4.0 license (https://creativecommons.org/licenses/by/4.0/). Published by Al-Kindi Centre for Research and Development, London, United Kingdom. 
World still placed Indonesia as the main producer of CPO with a production volume of 23.9 million tons of CPO/year. This shows that Indonesia has enormous potential to produce biogasoline or other fuel oils derived from palm oil (Jatmiko, Qodri., 2021).

The process of making biofuel from palm oil has been carried out by various methods such as esterification, transesterification, and cracking. Cracking is the process of breaking a high molecular weight hydrocarbon compound into a lower molecular weight compound by breaking the carbon chain bonds $(\mathrm{C}-\mathrm{C})$. The cracking reaction is divided into 2, namely: thermal cracking and catalytic cracking. Thermal cracking or pyrolysis is a reaction to break the bonds of hydrocarbon compounds due to the influence of thermal (high temperature). The mechanism of the thermal cracking reaction is through the formation of free radicals in forming the final product. The catalytic cracking reaction is the reaction of cracking(cracking) using a catalyst material (heterogeneous catalysts) as the material is capable of accelerating the reaction rate to achieve equilibrium and produce a final product through the reaction of the carbonium ion formation mechanism. (S, Donatus. 2015).

Catalytic cracking has advantages over the methods used to process triglycerides. Among them, the products of catalytic cracking are gas, organic liquid products, water, and soda. Organic liquid products include (Aldehydes, ketones, carboxylic acids, and hydrocarbons such as paraffin, olefins, and naphthenic) whose boiling points correspond to gasoline, kerosene, and diesel. Both reaction temperatures are lower than those of pyrolysis, and large molecules are broken down into simpler molecules through dehydration, dehydrogenation, deoxygenation, and decarboxylation (Jovas et al., 2015).

The purpose of this study was to determine the characteristics of the fuel produced using Na-bentonite and TKNTT catalysts. Over the centuries, fossil fuels have been used in many aspects of life, but these fuels are non-renewable and will eventually run out. The scarcity of fuel now makes people have to look for alternative energy sources that are easily renewable (renewable fuels), one of which is biofuel. In recent years, many developments have been carried out on raw materials for making biofuels from plants, especially oil palm, this is because this fuel is non-toxic and does not contain nitrogen and sulfur compounds. Palm stearin is a derivative product of palm oil which is solid at room temperature and can be used as a raw material for the production of biofuel(Chuckling and Ratnawali, 2014).

Alternative fuels (biofuels) can be produced from various varieties of renewable natural resources. Among them, triglycerides have a very important role and are compounds that are commonly found in vegetable and animal oils (Doronin et al.,2012). Several techniques have been studied to convert vegetable oils and animal fats into biofuels. One of the most promising techniques for producing alternative fuels from vegetable and animal oils is pyrolysis. Pyrolysis is also known as thermal cracking and catalytic cracking. (Xu et al.,2013).

\section{Literature Review}

Anando et al., 2016) have investigated the production of biogasoline from palm oil through a catalytic cracking reaction with a gamma-alumina catalyst and obtained the peak results of the compounds analyzed by GC-MS similar to the peaks of commercial gasoline and obtained straight-chain hydrocarbon compounds at $\mathrm{C}_{6}-\mathrm{C}_{11}$. Mancio et al.,(2016) have done a catalytic thermal cracking of the crude palm oil at a pilot scale using a catalyst $\mathrm{Na}_{2} \mathrm{CO}_{3}$. This study produced a conversion of $60 \%$ and produced biofuel with an acid value of most rendah. Senyawa-hydrocarbons The resulting product has characteristics similar to petroleum diesel.

The latest research was also carried out by Friskila, S (2020) namely the use of palm oil into hydrocarbon fuels with Saponification Pretreatment through the cracking of $\mathrm{CPO}$ with $\mathrm{Fe} / \mathrm{Cr}$ catalyst. In this study, a chromatogram with the largest area was produced for the compound 1-Dodecane $\left(\mathrm{C}_{12} \mathrm{H}_{24}\right)$ which was equivalent to the fraction biodiesel.

Jonathan, $\mathrm{H}$ (2021) also conducted a similar study, in which Crude Palm Oil was cracked using Na-Bentonite and $\mathrm{Fe}_{2} \mathrm{O}_{3}$ as catalysts. From this research, the result is that there is a dominant compound which is a straight-chain hydrocarbon compound, namely 1 -pentadecane $\left(\mathrm{C}_{15} \mathrm{H}_{30}\right)$.

The effect of pore size on catalytic cracking has been studied. (Sadramelli, M, S. 2016) has investigated the effect of catalyst pore size on n-octane catalytic cracking activity using ZSM-5, HZMS-5, and H $\beta$ catalysts with small, medium, and large pore sizes. The selectivity of olefins increases with a decrease in the pore size of the catalyst. Another study also examined the effect of aluminum (Al) in the catalyst and concluded that a lower amount of aluminum (Al) in the catalyst resulted in higher olefin production, this was due to the slightly lower amount of aluminum (Al) in the acid site in the catalyst. the catalyst which results in higher selectivity for olefins. In this study, researchers will crack CPO by comparing the use of two catalysts, namely Na-bentonite and $\mathrm{Al}_{2} \mathrm{O}_{3}$ from limestone soil of NTT. Researchers want to compare the amount of conversion of CPO into biogasoline and biodiesel fractions produced on each catalyst. 


\section{Research methods}

Preliminary analysis was carried out on the CPO samples to determine the value of free fatty acids. Then put $100 \mathrm{~g}$ of CPO sample into a glass beaker and then heated at a temperature of $90^{\circ} \mathrm{C}$ then added $30 \mathrm{~g}$ of $\mathrm{NaOH}$ and then heated while stirring with a magnetic stirrer until the soap was formed. The soap was allowed to stand for 24 hours and then put into a stainless steel reactor and then heated on a gas stove at a temperature of $250^{\circ} \mathrm{C}-360^{\circ} \mathrm{C}$ for 2 hours while connected to a distillation device. The resulting distillate is accommodated. Each $100 \mathrm{~mL}$ of the resulting distillate was added with $5 \mathrm{~g}$ of Na Bentonite and $5 \mathrm{~g}$ of NTT lime soil. Cracked by heating on a gas stove at a temperature of $250-350^{\circ} \mathrm{C}$ for 2 hours while connected to a distillation apparatus. The resulting distillate is accommodated. The resulting distillate was analyzed using GC-MS, FT-IR, and Calculated Cetane Index $(\mathrm{CCl})$.

\section{Results and Discussion}

\section{Free Fatty Acid Analysis of CPO}

The results of the analysis of CPO fatty acids were determined using the following calculations:

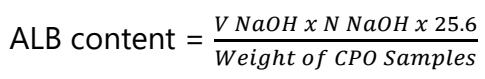

Determination of free fatty acids of CPO samples was carried out 3 times analysis then the value of free fatty acids was determined from the average value.

Table 1. Analysis of free fatty acid (ALB) levels of CPO

\begin{tabular}{|c|c|c|c|c|c|}
\hline Experimental & Sample Weight & $\begin{array}{l}\text { Volume } \\
(\mathrm{mL})\end{array}$ & $\mathrm{NaOH}$ & Normality $\mathrm{NaOH}$ & ALB value \\
\hline 1 & 5,214 & 8.6 & & 0.1 & 4.24 \\
\hline 2 & 5.514 & 9.04 & & 0.1 & 4.20 \\
\hline 3 & 5,120 & 8,44 & & 0.1 & 4.22 \\
\hline Average & & & & & 4.22 \\
\hline
\end{tabular}

ALB levels in the CPO samples used in this study were $4.22 \%$. ALB levels indicate the level of product damage due to the breakdown of triglycerides into glycerol and free fatty acids. A high acid number indicates that the free fatty acids present in vegetable oil are also high so that the quality of the oil is even lower (Winarno, 2004). According to widya (2015), There are various grades of CPO (Crude Palm Oil) that can be used as an alternative to raw materials, biofuel namely standard CPO (FFA < 5\%), off-grade CPO (FFA 5 20\%), waste CPO (FFA 2070 Determination of free fatty acids can be carried out using the alkaline titration method $(\mathrm{NaOH})$. In principle, this method analyzes free fatty acids based on the amount of $\mathrm{NaOH}$ used in the titration to form a pink sample color. This is in accordance with the statement of Maligan (2014) which stated that the principle of acidbase titration is the analysis of the amount of free fatty acids in a sample which is equivalent to the amount of base ( $\mathrm{NaOH}$ ) added in the titration which is marked by a change in the color of the sample to pink.

\section{Pretreatment of CPO with Saponification}

The first step of this research is to perform cracking of CPO samples with saponification pretreatment. At this stage, a distillate will be produced. According to Friskilla's research (2020), the distillate used The resulting biodiesel fraction. Furthermore, the resulting distillate will be cracked using Na-Bentonite and TKNTT catalysts. At this stage, Palm Oil / Crude Palm Oil is reacted with $\mathrm{NaOH}$ base to form soap (salt of fatty acid triglycerides). Palm Oil Saponification Reaction produces soap (triglyceride fatty acid salt) based on the following reaction:

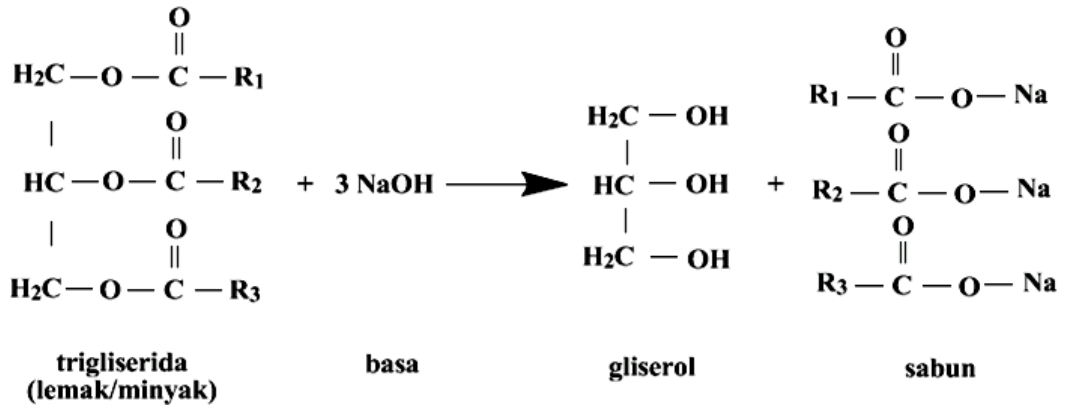

Figure 1. Reaction Saponification 
The saponification reaction of $\mathrm{CPO}$ uses $\mathrm{NaOH}$ base which functions to stabilize the reactive groups found in triglycerides. Stabilization or neutralization of these reactive groups is important because it can prevent polymerization and polycondensation reactions triggered by the state of the reactive groups. The reactive groups in question are ester, hydroxyl, and unsaturated carbon bonds (double bonds).

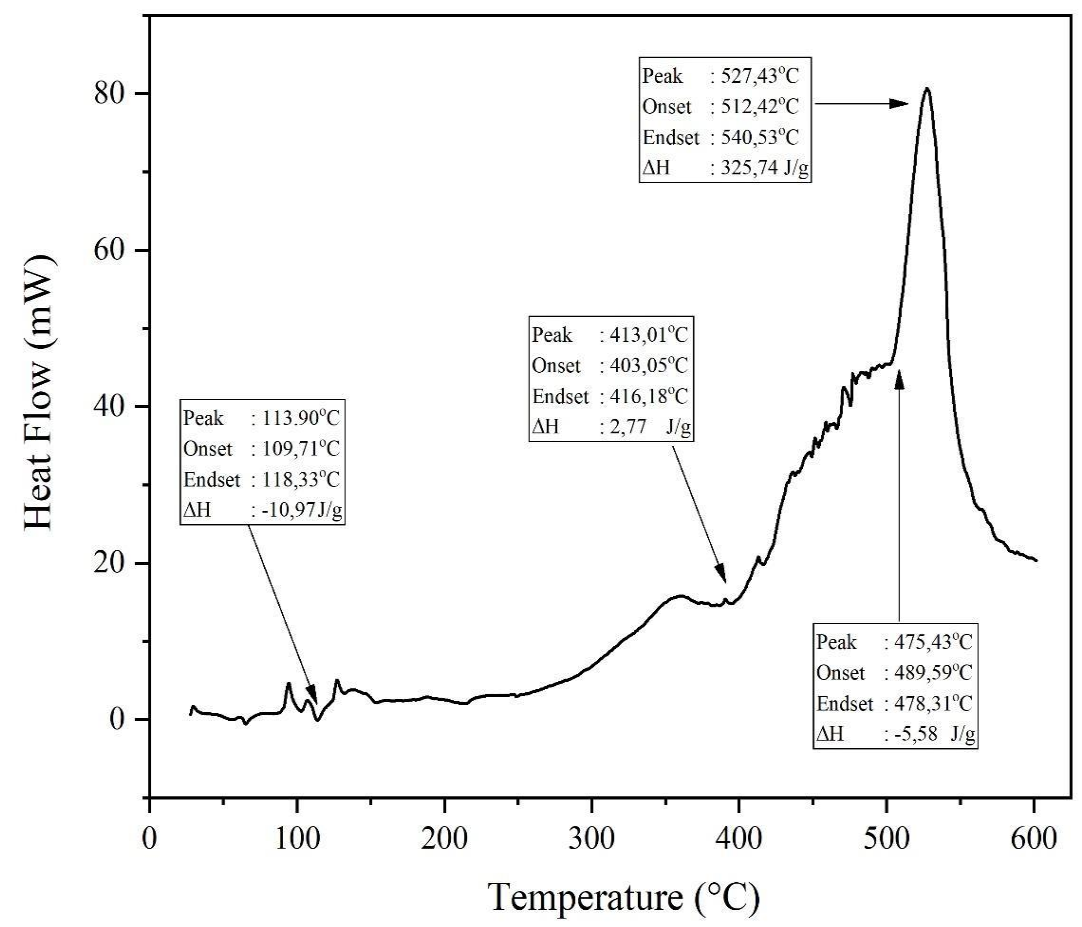

Figure 2. Thermogram of DSC from CPO saponification

Thermal analysis with DSC on the results of CPO saponification in the form of soap is shown in Figure 2. This shows that there is a peak indicating the glass transition $\left(T_{g}\right.$ ) at $94.45^{\circ} \mathrm{C}$, crystallization peak at $413^{\circ} \mathrm{C}$, peak melting $\left(T_{m}\right)$ at $475.43^{\circ} \mathrm{C}$, and a decomposition peak at $527.43^{\circ} \mathrm{C}$ Based on the data obtained, it shows that the temperature required for the process of cracking soap into fuel without using a catalyst is $527.43^{\circ} \mathrm{C}$. This data is in accordance with previous research (Supeno et al., 2021). The addition of a catalyst in the cracking process is needed to reduce the activation energy so that the temperature required for the cracking process can be lowered. CPO catalytic cracking process of saponification pretreatment results conducted in the temperature range $250-350^{\circ} \mathrm{C}$. Determination of the cracking temperature was envisaged from the boiling point of biodiesel is similar to diesel fuel in the range of $270-350^{\circ} \mathrm{C}$.

\section{Catalytic Cracking CPO saponification results}

This research does catalytic cracking in stages, where the results of catalytic cracking using a $\mathrm{Fe} / \mathrm{Cr}$ catalyst against the saponified CPO will be carried out again by catalytic cracking using Na-bentonite and TKNTT catalysts. During the cracking process, the CPO saponification products in the form of soap and glycerol will be converted into hydrocarbon compounds in the presence of a Fe/Cr catalyst from reactor stainless steel. Based on the results of research conducted by Supeno et al., (2021), catalytic cracking at this stage produces a biodiesel fuel fraction. In this study, the cracking process was carried out again using Na-bentonite and TKNTT catalysts, where biodiesel fuel would be converted into biogasoline fuel which was analyzed using GC-MS.

The catalytic cracking process occurs at a temperature of $250-350^{\circ} \mathrm{C}$ and is able to produce energy that causes excitation of electrons from the catalyst ( $\mathrm{Fe} / \mathrm{Cr}$, Na-bentonite, TKNTT). These electrons will fill the empty orbitals of the carbon atoms that make up the long hydrocarbon chain until the orbitals are full and become saturated. At this time there will be a cracking process. Pretreatment distillate catalytic cracking process CPO produce a yield of $77 \%$ calculated as follows:

Yield

$=\frac{\text { VolumeCPO before cracking }}{\text { Volume CPOafter cracking }} \times 100 \%$

mass CPOsample $=100 \mathrm{~g}$

density of oil $\quad=0.9 \mathrm{~g} / \mathrm{mL}$ 


$$
\begin{array}{ll}
- & =\frac{\operatorname{mass}(\mathrm{g})}{\text { Volume }(\mathrm{ml})} \\
\mathrm{V}_{\mathrm{CPO}} & =0.9 \times 100=90 \mathrm{~mL} \\
\text { Yield } & =\frac{70 \mathrm{ml}}{90 \mathrm{ml}} \times 100 \% \\
\text { Yield } & =0.77 \times 100 \%=77.77 \%
\end{array}
$$

\begin{tabular}{|c|c|c|c|}
\hline Cracking catalyst & $\begin{array}{l}\text { The volume before } \\
\text { cracking }(\mathrm{mL})\end{array}$ & $\begin{array}{l}\text { Volume after cracking } \\
(\mathrm{mL})\end{array}$ & Yield (\%) \\
\hline Na bentonite & 70 & 65 & $72.2 \%$ \\
\hline TKNTT & 70 & 67 & $72.2 \%$ \\
\hline
\end{tabular}

Distillate obtained is then cracked back on heating $180-240^{\circ} \mathrm{C}$ using different catalysts namely Na-Bentonite and TKNTT so that the distillate is obtained as follows:

Table 2. Fuel from the catalytic cracking of CPO

$\begin{array}{ll}\text { Yield Na-bentonite } & =\frac{65}{90} \times 100 \% \\ \text { Yield Na-bentonite } & =72.2 \% \\ \text { Yield TKNTT } & =\frac{67}{90} \times 100 \% \\ \text { Yield TKNTT } & =74.4 \%\end{array}$

\section{Analysis X-Ray Fluorescence (XRF)}

The chemical elements in bentonite and limestone soils of NTT analyzed using XRF are shown in Table 4.2. The results of X-ray diffraction using X-Ray Fluorescence (Panalytical minipal IV) base metal in Appendix 1 show that bentonite was identified as dominant elements in the form of $\mathrm{Si}, \mathrm{Al}, \mathrm{Fe}, \mathrm{P}, \mathrm{Ca}$, and Ti, while the TKNTT samples identified elements as $\mathrm{Ca}$ and $\mathrm{Si}$ only. . It can be seen that bentonite for Si elements has an intensity of $7.529 \mathrm{cps} / \mathrm{mA}$ while other elements have an intensity of fewer than $7.529 \mathrm{cps} / \cdot \mathrm{A}$, so it can be assumed that the largest constituent of bentonite is Si. This is in accordance with the results of previous studies (Abukhadra et al., 2019). The element Ca is the largest constituent of TKNTT with an intensity of $37.359 \mathrm{cps} / \cdot \mathrm{A}$.

Table 3. XRF test results for chemical elements in bentonite and KTNTT

\begin{tabular}{llll}
\hline Bentonite & Mass\% & TKNTT & Mass\% \\
\hline $\mathrm{Si}$ & 12.5 & $\mathrm{Ca}$ & 5.87 \\
$\mathrm{Al}$ & 4.3 & $\mathrm{Si}$ & 0.835 \\
$\mathrm{Fe}$ & 4.07 & $\mathrm{Te}$ & 0.83 \\
$\mathrm{P}$ & 1.27 & $\mathrm{P}$ & 0.227 \\
$\mathrm{Ca}$ & 1.14 & $\mathrm{~S}$ & 0.212 \\
$\mathrm{Ti}$ & 0.465 & $\mathrm{Sb}$ & 0.184 \\
$\mathrm{~K}$ & 0.453 & $\mathrm{~K}$ & 0.084 \\
$\mathrm{Te}$ & 0.273 & $\mathrm{Sr}$ & 0.0705 \\
$\mathrm{~S}$ & 0.214 & $\mathrm{Fe}$ & 0.044 \\
$\mathrm{In}$ & 0.139 & $\mathrm{Cl}$ & 0.0146 \\
$\mathrm{Sb}$ & 0.0991 & $\mathrm{Mn}$ & 0.0036 \\
$\mathrm{Cl}$ & 0.096 & $\mathrm{Zr}$ & 0.003 \\
$\mathrm{Mn}$ & 0.0959 & $\mathrm{Ba}$ & 0.0017 \\
$\mathrm{~V}$ & 0.0332 & $\mathrm{Co}$ & 0.0013 \\
$\mathrm{Co}$ & 0.0249 & $\mathrm{Ni}$ & 0.0011 \\
$\mathrm{Cr}$ & 0.0139 & $\mathrm{Cu}$ & 0.001 \\
$\mathrm{Zr}$ & 0.012 & $\mathrm{Ta}$ & 0.0008 \\
$\mathrm{Zn}$ & 0.0089 & $\mathrm{Y}$ & 0.0006 \\
$\mathrm{Cu}$ & 0.0073 & $\mathrm{Zn}$ & 0.0005 \\
$\mathrm{Ni}$ & 0.0067 & $\mathrm{Ga}$ & 0.0004 \\
$\mathrm{Sr}$ & 0.0058 & $\mathrm{~Pb}$ & 0.0004 \\
\hline
\end{tabular}




\begin{tabular}{llll}
\hline $\mathrm{Ba}$ & 0.0045 & $\mathrm{As}$ & 0,0001 \\
$\mathrm{Hf}$ & 0,0036 & $\mathrm{Ag}$ & 0,0001 \\
\hline
\end{tabular}

Based on XRF test results, it can be concluded that bentonite is assumed to have dominant compounds in the form of $\mathrm{SiO}_{2}$ (Quartz), $\mathrm{CaO}$ (Lime), $\mathrm{Fe}_{2} \mathrm{O}_{3}$ (Hematite), $\mathrm{FeTiO}_{3}$ (Ilmenite), and $\mathrm{Al}_{2} \mathrm{O}_{3}$ (Corundum). While TKNTT has dominant compounds in the form of $\mathrm{CaO}, \mathrm{CaCO}_{3}$ (Calcite), and $\mathrm{Ca}(\mathrm{OH})_{2}$ (Portlandite). Where the presence of these compounds is discussed further in XRD analysis.

\section{Analysis of X-Ray Diffraction (XRD)}

Na-Bentonite and TKNTT XRD diffractograms are shown in Figure 3.

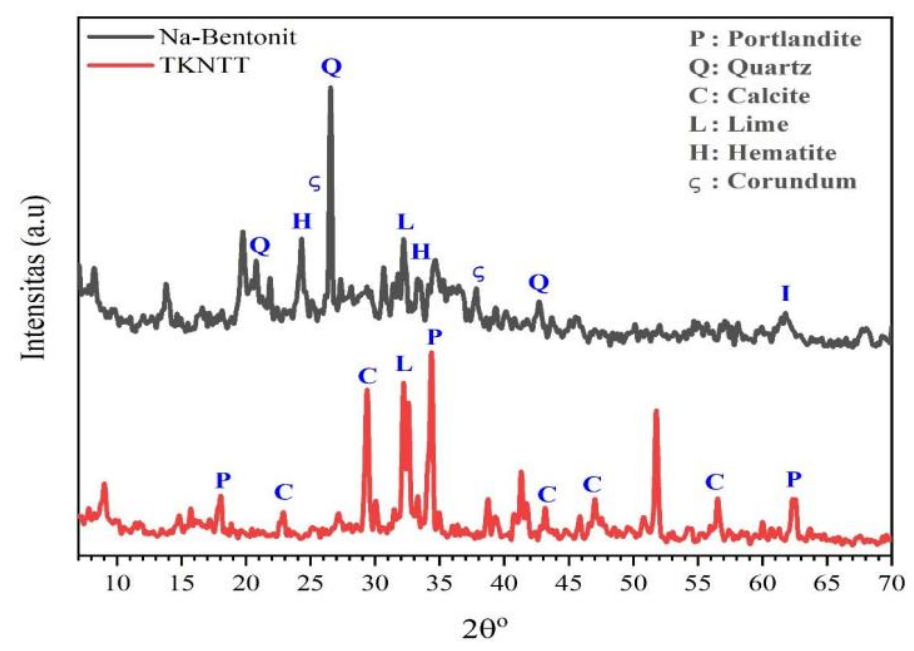

Figure 3. XRD Diffractogram of Na-Bentonite Catalyst and TKNTT

From the XRD analysis, there is a diffraction peak at $2 \cdot=8.1^{\circ} ; 19.7^{\circ}$; and $34.6^{\circ}$ with diffraction planes (001), (110), and (110) respectively being the diffraction pattern of Na-bentonite with a hexagonal structure (JCPDS No. 79-1910) (Guo et al., 2019). This shows that the pillarization of bentonite with $\mathrm{Na}$ metal has been successfully carried out. However, there is a diffraction peak at $2^{-}=20.7^{\circ} ; 26.5^{\circ}$; and $28.2^{\circ}$ which is the diffraction peak of bentonite material (JCPDS No. 29-1499). This shows that there is still bentonite that does not react to form Na-bentonite (Naik \& Meivelu, 2020).

Based on the results of XRF and XRD analysis, Na-bentonite indicates the presence of Quartz as the most dominant compound. Other crystalline phases such as Lime, Corundum, Hematite, and Ilmenite were identified as impurities. diffraction peaks Quartz with a hexagonal structure are at $2 \cdot=20.7^{\circ} ; 26.5^{\circ}$; and $42.7^{\circ}$ with the respective lattice planes (100), (011), and (200) according to JCPDS data No. 46-1045 (Wijaya et al., 2021). mineral compounds Corundum with the rhombohedral structure are indicated by the presence of $2 \cdot$ diffraction peaks at angles of $26^{\circ}(012)$ and $37.8^{\circ}$ (110) (JCPDS No. 10-0173). minerals Hematite and Ilmenite with a hexagonal structure were also found, each with a characteristic 2 - diffraction peak at an angle of 24.2 $2^{\circ}(10-2)$; $33.2^{\circ}$ (104), and 61.7 (12-4) according to JCPDS data No. 96-101-1241 for Hematite and JCPDS No. 96-101-1034 for Ilmenite.

The TKNTT diffractogram shows that $\mathrm{CaCO}_{3}$ (Calcite) is the most dominant mineral compared to other minerals such as Portlandite and Lime. 2. diffraction peak which is owned by the form of the mineralTKNTT calcite with rhombohedral crystal system is shown at an angle of $22.8^{\circ} 29.3^{\circ} ; 43.1^{\circ} ; 46.9^{\circ}$; and $56.5^{\circ}$ have lattices with planes (012), (104), (202), (024), and (211) (JCPDS No. 47-1743). While the $2 \cdot$ diffraction peak which indicates the mineral $\mathrm{Ca}(\mathrm{OH})_{2}$ is $18^{\circ} ; 34.3^{\circ}$; and $62.6^{\circ}$ with (001), (101), and (201) respectively are diffraction patterns Portlandite with a hexagonal crystal system according to JCPDS data No. 44-1481 (Li et al., 2015). The 2- diffraction peak at an angle of $32.1^{\circ}$ with the lattice plane (111) on both catalysts indicated the presence of $\mathrm{CaO}$ (mineralsLime)(JCPDS No. 96-100-0045). The presence of these compounds is in accordance with the results of testing using XRF. 


\section{Analysis Scanning Electron Microscope (SEM)}

Analysis of Na-bentonite catalyst morphology and TKNTT using SEM with a magnification of 500 and 2000 x shown in Figure 4.

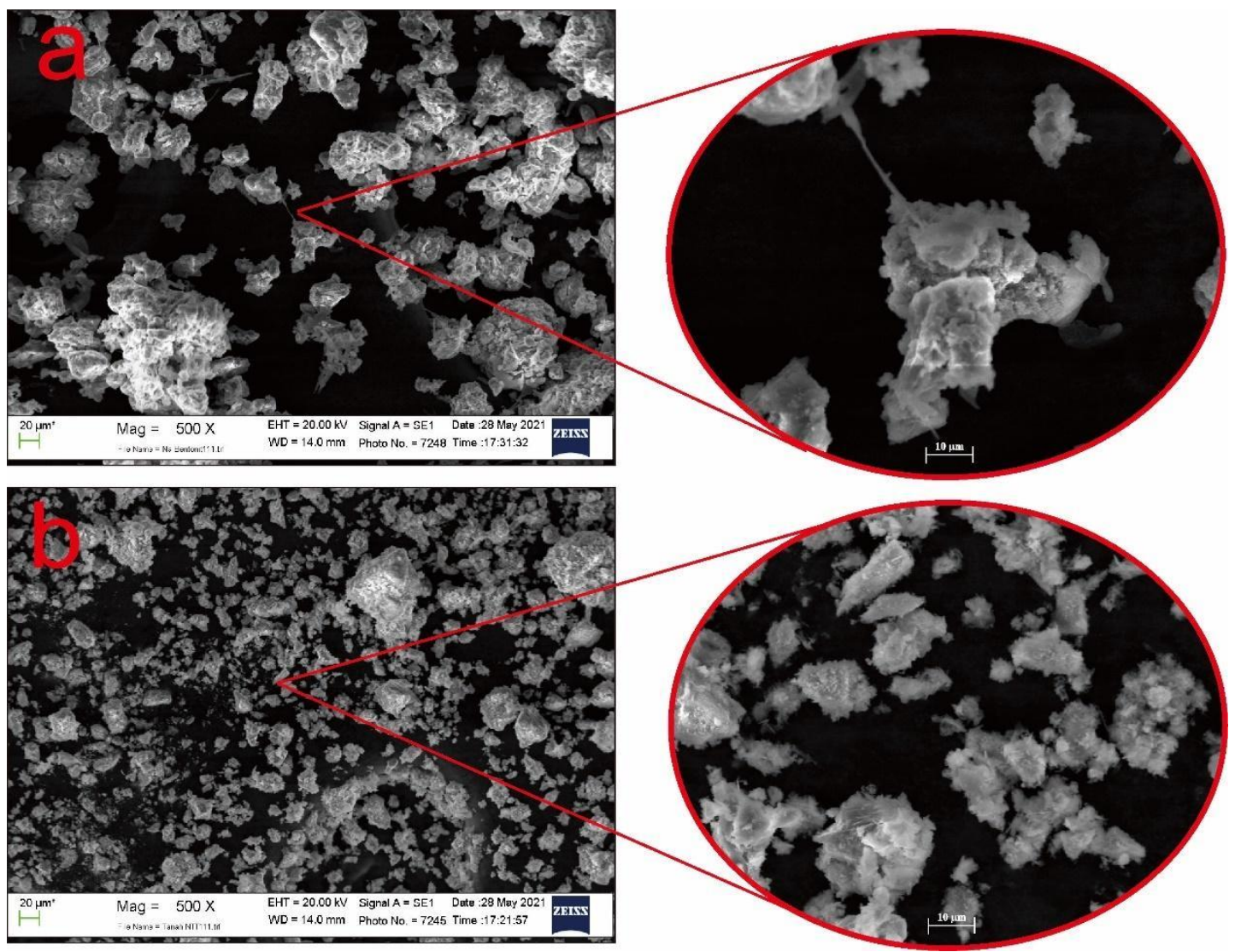

Figure 4. Microstructure of SEM catalyst a). Na-Bentonite and b). Summit at 500 and $2000 \times$ magnification

Na-bentonite micrographs have surface characteristics that appear as groups of agglomerated particles consisting of layers with smooth surfaces that are stacked on top of each other. From Figure $4 \mathrm{a}$, it can be seen that there is a porous character and the catalyst crystals are sphere-like crystals. Compared to Figure $4 \mathrm{~b}$, the TKNTT catalyst has a rougher surface. This is assumed to come from the combination of $\mathrm{CaCO}_{3}, \mathrm{CaO}$, and $\mathrm{Ca}(\mathrm{OH})_{2}$ which has a surface structure like a cube (cubic).

\section{Catheterization of Alternative Fuels}

Analysis Fourier Transform Infrared Spectroscopy (FTIR)

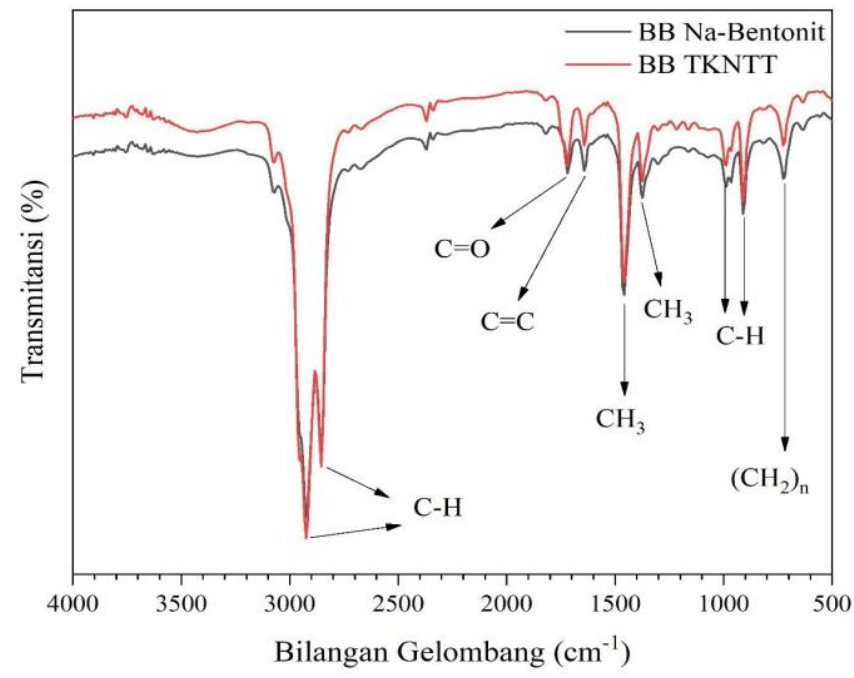

Figure 5. FTIR Spectra of Fuel from catalytic cracking using Na-Bentonite and TKNTT 
The FT-IR spectra of the fuel (BB) resulting from the catalytic cracking of the CPO pretreatment distillate are shown in Figure 5 . The FT-IR spectra of the two fuels resulting from catalytic cracking have identical characteristics in terms of the presence of functional groups present in the fuel. The summary of FT-IR spectra shown in Table 4. explains that there are absorption peaks at wave numbers 2924.09 and $2854.65 \mathrm{~cm}^{-1}$ which are identified as vibrations stretching $\mathrm{CH}$ asymmetric of the methylene group and vibrations stretching $\mathrm{CH}$ symmetry of the methyl group in the compound. alkane. This data is reinforced by the vibrations bending asymmetric and $\mathrm{CH}$ symmetry of the methyl group at wavenumbers 1458.18 and $1373.32 \mathrm{~cm}^{-1}$ (Stuart, 2005 ; Withrow, 2016). The weak absorption peak in the wavenumber region of $1720.50 \mathrm{~cm}^{-1}$ indicates that the fuel produced has a $C=O$ group. The presence of the $C=C$ group shown at wave number $1643.35 \mathrm{~cm}^{-1}$ indicates that there are olefin hydrocarbon compounds. The absorption peaks at wave numbers 964.41 and $910.40 \mathrm{~cm}^{-1}$ indicate the presence of a $\mathrm{CH}$ group. The presence of an absorption peak at a wavenumber of $725.23 \mathrm{~cm}^{-1}$ indicates that the fuel resulting from catalytic cracking is a long chain hydrocarbon compound, $\left(\mathrm{CH}_{2}\right)$ n. Each absorption peak contained in the fuel is a characteristic possessed by hydrocarbon compounds (Supeno et al., 2021).

Table 4. Summary of FT-IR spectra of fuel catalytic cracking

\begin{tabular}{llll}
\hline Wave Number $\left(\mathrm{cm}^{-1}\right)$ & & Type of Group & Vibration Type \\
BB Na-bentonite & BB TKNTT & & \\
\hline 2924.09 & 2924.09 & $\mathrm{CH}$ asym & Stretching \\
2854.65 & 2854.65 & $\mathrm{CH}$ sym & Stretching \\
1720.50 & 1720,50 & $\mathrm{C}=\mathrm{O}$ & Stretching \\
1643,35 & 1643,35 & $\mathrm{C}=\mathrm{C}$ & Stretching \\
1458,18 & 1458,18 & $\mathrm{CH}\left(\mathrm{CH}_{3}\right)$ asym & Bending \\
1373,32 & 1373,32 & $\mathrm{CH}\left(\mathrm{CH}_{3}\right)$ sym & Bending \\
964,41 & 964,41 & $\mathrm{CH}$ & Stretching \\
910,40 & 910,40 & $\mathrm{CH}$ & Stretching \\
725,23 & 725,23 & $(\mathrm{CH}) \mathrm{n}$ & Stretching \\
\hline
\end{tabular}

Analysis of Gas Chromatography-Mass Spectrometry (GC-MS)

Alternative fuel (biofuel) produced from the cracking process using Na-bentonite and TKNTT catalysts then analyzed using the GC-MS instrument to analyze the fuel fraction contained in the sample and its constituent compounds. The chromatogram of the fuel produced from the catalytic cracking of the CPO distillate is shown in the figure below.



Figure 6. Chromatogram of GC-MS fuel resulting from catalytic cracking using Na-bentonite as a catalyst

The chromatogram in Figure 6 shows that there are 44 compound fractions identified in the fuel resulting from catalytic cracking using a Na-bentonite catalyst. The results of the GC-MS analysis showed that there were 5 constituent compounds with the highest peaks, which are summarized in Table 5. 
Table 5. Chromatogram of compounds with the highest peaks from BB Na-bentonite

\begin{tabular}{llllll}
\hline Peak & $\begin{array}{l}\text { No. The } \\
\text { highligh } \\
\text { t of }\end{array}$ & $\begin{array}{l}\text { the compound } \\
\text { name }\end{array}$ & $\begin{array}{l}\text { Molecular } \\
\text { formula }\end{array}$ & $\begin{array}{l}\text { Retention } \\
\text { (Minutes) }\end{array}$ & Time \\
\hline 1 & 27 & 1-Undekena & $\mathrm{C}_{11} \mathrm{H}_{22}$ & 29.759 & 15.48 \\
2 & 28 & n-decane & $\mathrm{C}_{10} \mathrm{H}_{29.957}$ & 22 & 13.17 \\
3 & 18 & 1-Dodecene & $\mathrm{C}_{12} \mathrm{H}_{24}$ & 27.052 & 10.29 \\
4 & 14 & n-Nonana & $\mathrm{C}_{9} \mathrm{H}_{20}$ & 24,423 & 7.71 \\
5 & 13 & 3-Undecane & $\mathrm{C}_{11} \mathrm{H}_{22}$ & 24,170 & 5.35 \\
\hline
\end{tabular}

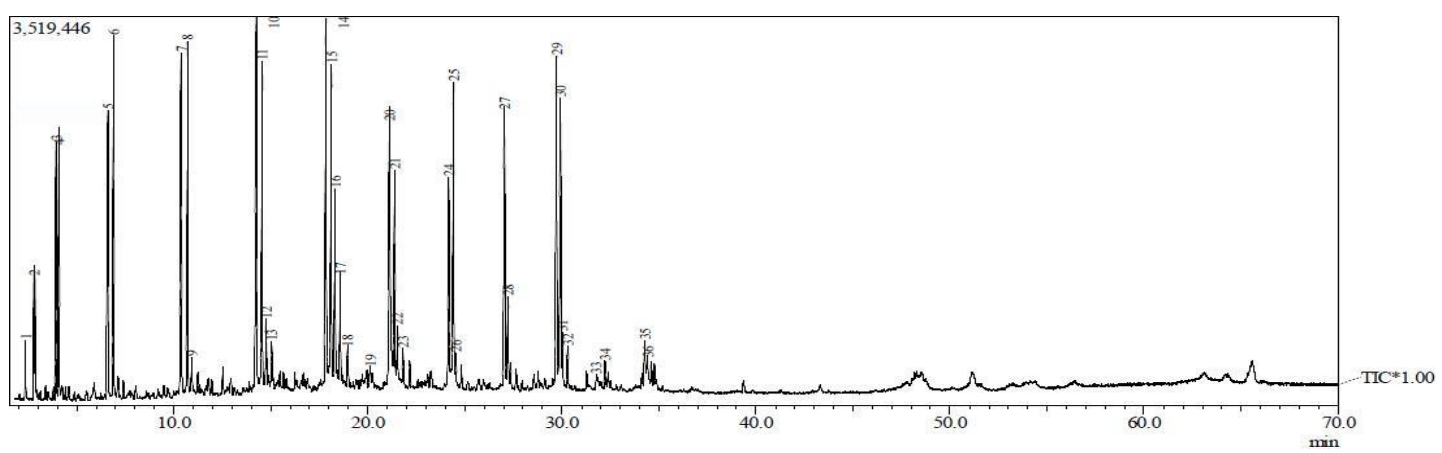

Figure 7. Chromatogram of GC-MS fuel resulting from catalytic cracking using TKNTT catalyst.

The chromatogram in Figure 7 shows that there are 36 fractions of compounds identified in the fuel resulting from catalytic cracking using TKNTT catalyst. The results of the GC-MS analysis show that there are 5 constituent compounds with the highest peaks which are summarized in Table 6.

Table 6. Chromatogram of compounds with the highest peaks from BB TKNTT

\begin{tabular}{llllll}
\hline Peak & $\begin{array}{l}\text { No. } \\
\text { Peak }\end{array}$ & Name of compound & $\begin{array}{l}\text { Molecular } \\
\text { formula }\end{array}$ & $\begin{array}{l}\text { Retention } \\
\text { (minutes) }\end{array}$ & time \\
\hline 1 & 14 & 1-Nonene & $\mathrm{C}_{9} \mathrm{H}_{18}$ & 17,836 & 6,49 \\
2 & 10 & Undecene & $\mathrm{C}_{11} \mathrm{H}_{22}$ & 14,241 & 6,02 \\
3 & 29 & 1-Dodecene & $\mathrm{C}_{12} \mathrm{H}_{24}$ & 29,725 & 5,86 \\
4 & 20 & 3-Undekena & $\mathrm{C}_{11} \mathrm{H}_{22}$ & 21,121 & 5,33 \\
5 & 7 & 1-Oktena & $\mathrm{C}_{8} \mathrm{H}_{16}$ & 10,373 & 5,28 \\
\hline
\end{tabular}

The results of the analysis of the fuel from the catalytic cracking of the CPO pretreatment distillate using the Na-bentonite catalyst showed that the biogasoline and biodiesel fractions were $61.36 \%$ and $38.63 \%$, respectively. Meanwhile, using the TKNTT catalyst produced biogasoline and biodiesel fractions of $88.88 \%$ and $11.11 \%$, respectively. Thus, in this study, the catalytic cracking of the CPO pretreatment distillate has the potential to produce more gasoline fractions than biodiesel fractions. The study of Supeno et al., (2021) produced fuel with a major fraction in the form of biodiesel from CPO using a Fe/Cr catalyst. Likewise, research conducted by Hutabarat (2021) conducted catalytic cracking using Na-Bentonite on saponified CPO to produce biodiesel fuel fraction. In this study, catalytic cracking was carried out in stages, where the results of the catalytic cracking using a Fe/Cr catalyst against the saponified CPO will be carried out again by catalytic cracking using Na-bentonite and TKNTT catalysts. From these data, it can be concluded that the catalytic cracking of saponified CPO produces a biodiesel fuel fraction, while the second catalytic cracking stage using $\mathrm{Na}$-bentonite and TKNTT catalysts produces a major fraction of fuel in the form of gasoline.

\section{Analysis of Bomb Calorimeter and $\mathrm{CCI}$}

Bomb calorimeter analysis was carried out to test the calorific value with the aim of knowing the number that states the amount of heat generated from the combustion process of a certain amount of fuel with oxygen. The standard calorific value of fuel based on the SNI-04-7182-2006 standard is 10,498 BTU/lb or about 5,832 cal/g. In this study, the calorific value of biodiesel combustion was $6101 \mathrm{cal} / \mathrm{g}$ using a Na-bentonite catalyst. Thus the fuel produced meets the Net Calorific Value according to the standard. 
The cetane number $(\mathrm{CN})$ is used to describe the ignition quality of diesel fuel. The ignition quality of diesel fuel can also be calculated using the Cetane Index (CI) method (EN ISO 4264, ASTM D 4737). The cetane number of a fuel is influenced by the elements contained in the fuel, such as the element carbon which is a source of combustion energy (Supeno et al., 2021). The standard cetane index that biodiesel must have is $>45$. Based on the CCl test results, the cetane index value was 62 using $\mathrm{Na}$ bentonite catalyst. Based on the data obtained and summarized in Table 5, it can be concluded that the fuel obtained in this study can be used as an alternative fuel candidate in the form of biogasoline that has met the specified standards.

\section{Conclusion}

1. The results of XRD and XRF analysis show that Na-bentonite is mostly composed of Quartz (SiO2) minerals, while TKNTT is mostly composed of $\mathrm{CaCO} 3$ minerals. The morphology of the catalyst analyzed using SEM showed that both catalysts had a large and porous surface. Where the Na-bentonite catalyst appears as crystals that are shaped like spheres (sphere-like crystals) while the TKNTT catalyst is in the form of a cube (cubic).

2. In accordance with the results of the FT-IR and GC-MS analysis, it can be concluded that the fuel fractions produced are biogasoline and biodiesel fractions. The biogasoline fraction is $88.88 \%$ (TKNTT) $61.36 \%$ (Na-Bentonite) and the biodiesel fraction is $11.11 \%$ (TKNTT) and $38.63 \%$ (Na-Bentonite). combustion was $6101 \mathrm{cal} / \mathrm{g}$ determined using a bomb calorimeter, and a cetane index of 62 which was analyzed using $\mathrm{CCl}$. Both types of hydrocarbon fuels have met the physical requirements that must be possessed by biogasoline fuel based on SNI standards.

\section{References}

[1] Abukhadra, MR, Ibrahim, SM, Yakout, SM, El-Zaidy, ME, \& Abdeltawab, AA (2019). Synthesis of Na+ trapped bentonite/zeolite-P composite as a novel catalyst for effective production of biodiesel from palm oil; Effect of ultrasonic irradiation and mechanism. Energy Conversion and Management, 196(June), 739-750. https://doi.org/10.1016/j.enconman.2019.06.027

[2] Atkins, PW (1997). Kimia Fisik Jilid 1. Edisi Keempat. Terjemahan Irma KartohadiProdjo. Jakarta : Erlangga

[3] BC Clark and AB Baird. (1992) Ultraminiaturize X-ray fluorescence spectrometer for in-situ geochemical analysis on Mars, Earth and Planetary Science Letters, vol. 19, no. 3, 359-368

[4] Benson, TJ, Hernandez, R., French, WT, Alley, EG, Holmes, WE, (2009). Elucidation of the catalytic cracking pathway for unsaturated mono-, di-, and triacylglycerides on solid acid catalysts. J. Mol. Catal. A: Chem. 303, 117-123

[5] Chua K., J, Ratnawali, S. (2014). Biogasoline from Catalytic Cracking of Refine Palm Oil Using H-ZSM-5 Catalyst. International Journal of Advanced In Chemical Engineering and Biological Sciences (1), 114-118

[6] Dachriyanus. (2004). Analisa Struktur Senyawa Organik. Padang : Lembaga Pengembangan Teknologi Informasi dan Komunikasi (LPTIK) Universitas Andalas

[7] Doronin, VP, Potapenko, OV, Lipin, PV, Sorokina, TP, (2013). Catalytic cracking of vegetable oils and vacuum gas oil. Fuel 106, $757-765$.

[8] Gerper. (2004). Biodiesel Production Technology. USA: lowa State University

[9] Guo, Y., Guo, Y., Tang, D., Liu, Y., Wang, X., Li, P., \& Wang, G. (2019). Sol-gel synthesis of new ZnFe2O4/Na-bentonite composites for simultaneous oxidation of $\mathrm{RhB}$ and reduction visible of $\mathrm{Cr}(\mathrm{VI})$ under light irradiation. Journal of Alloys and Compounds, 781(Vi), 1101-1109. https://doi.org/10.1016/j.jallcom.2018.12.050

[10] Gunstone FD, Padley FB. (1997). Lipids Technologies and Applications. New York: Marcel Dekker Inc.

[11] Han U. (2015). Quality Improvement Of Oil Palm Shell- derived Pyrolysis oil via catalytic deoxygenation over NiMoS/¥-Al2O3, Fuel 143,512518

[12] Hariyadi P. (2009). Mengenal Minyak Sawit dengan Beberapa Karakter Unggulnya. Jakarta : Gabungan Pengusaha Kelapa Sawit Indonesia (GAPKI)

[13] Hassan S.N. (2015). Biogasoline: an out of the Box Solution to the Food Fuel and Land Use Competitions. Energy Conversion and Management, 89, 349-367

[14] Heny. (2007). Proses Perengkahan Minyak Sawit menggunakan Katalis Jenis DH Prosiding Seminar Nasional Fundamental dan Aplikasi Teknik Kimia'. Surabaya : Institut Teknologi Sepuluh November

[15] Hutabarat, JAR (2021). Studi Perbandingan Na-Bentonit dan Fe2O3-Bentonit Sebagai Katalis Perengkah Crude Palm Oil (CPO) Menjadi Bahan Bakar Hidrokarbon. Universitas Sumatera Utara.

[16] Knothe G, Gerpen Jv, Krahl J. (2005). The Biodiesel Handbook, 9-10 Champaign Illinois USA: AOCS Press

[17] Kurt C, Bittner. (2006). Sodium Hydroxide In Ullmann's Encyclopedia of Industrial Chemistry. Wiley Online Library: Bayer Material Science SG, Leverkusen Germany

[18] Li, H., Niu, SL, Lu, CM, \& Cheng, SQ (2015). The stability evaluation of lime mud as transesterification catalyst in resisting CO2 and H2O for biodiesel production. Energy Conversion and Management, 103, 57-65. https://doi.org/10.1016/j.enconman.2015.06.039

[19] Lovás, P., Hudec, P., Hadvinová, M., Ház, A., (2015). Conversion of rapeseed oil via catalytic cracking: effect of the ZSM-5 catalyst on the deoxygenation process. Fuel Process. Technol. 134, 223-230.

[20] McGee, H. (2004). On Food and Cooking: Thes Science and Lore of the Kitchen. Scribner. United States of America

[21] Naik, BD, \& Meivelu, U. (2020). Experimental studies on sodium methoxide supported bentonite catalyst for biodiesel preparation from waste sunflower oil. Environmental Progress and Sustainable Energy, 39(4), 1-14. https://doi.org/10.1002/ep.13390

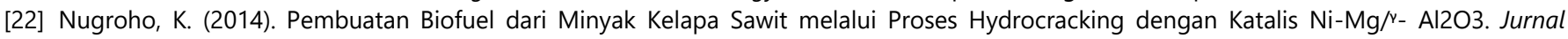
Teknik POMITS Vol 3 No. 2 
[23] Nurhadi M. (1999). Pembuatan dan Karakterisasi Katalis Kromium Zeolit Alam Perengkahan Fraksi Minyak Bumi. Tesis S2 Program Pasca Sarjana Universitas Gajah Mada : Yogyakarta

[24] Ong, YK, Bhatia, S., (2010). The current status and perspectives of biofuel production via catalytic cracking of edible and non-edible oils. Energy 35, 111-119.

[25] Perry RH, Green DW, (1984). Perry's Chemical Engineer's Handbook. 6th. ed. Mcgraw Hill Co., International Student Edition, Kogakusha, Tokyo.

[26] Pradipta O, S. (2008). Studi Komparasi untuk Kerja Mesin dan Pengaruh Kenaikan Cetane Number pada Campuran Biodiesel Minyak Jagung dengan Minyak Solar Murni. Essay. Jakarta : Teknik Mesin Universitas Indonesia Renewable and Sustainable Energy Reviews. Volume 12,24042421

[27] Reeves J. B. (1979). Agriculture handbook. Dalam JB Reeves, Consumer and Food Economics Institute (hal. 4). Washington, DC: US Dept. of Agriculture.

[28] Sastrosatomo S. (2003). Budidaya Kelapa Sawit. Jakarta: Agromedia Pustaka. Halaman 3

[29] S,Sumathi et al. 2008. Utilization of Oil Palm as a Source of Renewable Energy in Malaysia

[30] Saepulloh S. 2008. Produksi Hidrokarbon Fraksi Gasolin dari Minyak Sawit dengan Pretreatment Saponifikasi melalui Perengkahan Katalitik dengan Katalis B2O3/ Al2O3. Jakarta : Skripsi

[31] Satterfield, C,N. 1980. Heterogeneous Catalysis in Practices.New York

[32] Supeno M, 2009. Interaksi Asam-Basa: Kimia Anorganik. Medan.

[33] Speight,J,G.2013. thermal Cracking. Heavy and Extra-Heavy Oil Upgrading Technologies. Science direct.15-38

[34] McGraw hill, et al. 2009. The Impacts and Opportunities of Oil Palm in Southeast Asia. Center For International Forestry Research (CIFOR): Indonesia

[35] Silverstein, et al. 1981. Spectronic Identification of Organic Compounds. John Willey Sons Inc : New York

[36] Stuart, BH (2005). Infrared Spectroscopy: Fundamentals and Applications. In Infrared Spectroscopy: Fundamentals and Applications. https://doi.org/10.1002/0470011149

[37] Supeno, M., Pratama, A., \& Kembaren, FR (2021). The use of palm oil as hydrocarbon fuel with saponification pretreatment through catalytic cracking with Fe/Cr catalyst. Rasayan Journal of Chemistry, 14(1), 647-652. https://doi.org/10.31788/RJC.2021.1416116

[38] Tambun,Rondang et al. 2016. Pembuatan Biofuel dari Palm Stearin dengan Proses

[39] Triyono. 1994. Kimia Fisika : Dasar-Dasar Kinetika dan Katalis. Departemen Pendidikan dan Kebudayaan . Direktorat Pendidikan Tinggi

[40] Widhyastuti, Y, Novita M, Danaharini R, 2009. X-Ray Diffractometer (XRD). Fakultas Teknik. Universitas Sebelas Maret.

[41] Wijaya, K., Kurniawan, MA, Saputri, WD, Tri Aryanti, W., Mirzan, M., Hariani, PL, \& Tikoalu, AD (2021). Synthesis of nickel catalyst supported on $\mathrm{ZrO} 2 / \mathrm{SO} 4$ pillared bentonite and its application for conversion of coconut oil into gasoline via hydrocracking process. Journal of Environmental Chemical Engineering, 9(4), 105399. https://doi.org/10.1016/j.jece.2021.105399

[42] Withrow, J. (2016). Infrared Spectroscopy (Revised Ed, Vol. 148). Research World.

[43] Xu, J., Jiang, J., Zhang, T., Daí, W., 2013. Biofuel production from catalytic cracking of triglyceride materials followed by an esterification reaction in a scale-up reactor. Energy Fuels 27, 255-261.

[44] YSO, R.Zakaria, ARMohammed, and S.Bhatia. 2004, "Catalytic Cracking of UsePalm Oil and Palm Oil Fatty Acids Mixture for the Production of Liquid Fuel: Kinetic Modeling ". School Of Chemical Engineering, Universiti Sains Malaysia, Perak. Malaysia.

[45] Z.W.Chen et al.2008. High Definition X-Ray Fluorescence: Principles and Techniques. Hindawi Publishing Corporation X-Ray Optics and Instrumentation Volume 2008, Article ID 31817. 